\title{
Leaf and stem trait variation and plant functional types in 113 woody species of a seasonally dry tropical forest
}

\section{Grupos funcionalles y variación en rasgos folliares y de tallo de 113 especies leñosas en un bosque seco tropical}

\author{
Carolina Castellanos-Castro ${ }^{1} \&$ Adrian C. Newton ${ }^{2}$ \\ Cítese como: Castellanos-Castro, C. \& Newton, A. (2015). Leaf and stem trait variation and plant functional types \\ in 113 woody species of a seasonally dry tropical forest. Colombia Forestal, 18(1), 117-138.
}

Recepción: 18 de julio de 2014

\begin{abstract}
In seasonally dry tropical forest (SDTF) plant trait variation has been associated with adaptation to light and water availability and a coordinated tolerance of plants to shortage of both resources has been proposed. We tested this hypothesis in a set of 113 species by analyzing the relationships amongst eleven leaf and stem traits that have been related to shade and drought tolerance. In addition, the usefulness of different types of functional classifications describing community plant trait variation was evaluated. Strong relationships were observed between leaf and stem traits, potentially conferring coordinated tolerance to shade and drought, and three axes of variation were identified by means of a principal component analysis. The first axis described leaf and stem economy, the second was related to leaf thickness and organization and the third was related to the trade-offs between leaf size, stem density and bark thickness. Stem density was correlated strongly with several plant traits, emphasizing its key role in explaining variation in life history strategies of SDTF species. Significant differences were found between functional groups categorized by phylogeny and leaf
\end{abstract}

Aprobación: 12 de diciembre de 2014

phenology, whereas for life forms differences were only observed for palms and bamboos.

Key words: drought, life form, phenology, phylogenetic group, resource use strategies, trade-offs.

\section{RESUMEN}

En los bosques secos tropicales (BST) la variación en rasgos vegetales se ha relacionado con adaptaciones a cambios en la disponibilidad de luz y agua y se ha propuesto una tolerancia coordinada a la escasez de ambos recursos. En este estudio probamos dicha hipótesis en un conjunto de 113 especies mediante el análisis de la relación entre once rasgos funcionales de hojas y tallos, que se han asociado con la tolerancia a la sombra y la sequía. Adicionalmente, evaluamos la utilidad de diferentes clasificaciones funcionales para describir la variación de los rasgos en la comunidad de plantas estudiada. Se observaron relaciones fuertes entre rasgos de las hojas y el tallo, otorgando potencialmente tolerancia a la sombra y la sequía, además se identificaron tres ejes de variación a través de un análisis de componentes principales. El primer eje se relacionó con la economía de hojas y tallo, el segundo con el

1 Fundación Ecosistemas Secos de Colombia. Calle 68 No 50-152, Barranquilla, Colombia. carcastellanos@ecosistemassecos.org, carcastellanosc@yahoo.es Autor para correspondencia

2 School of Applied Sciences, Bournemouth University. Fern Barrow, Poole, Dorset, BH12 5BB, United Kingdom. anewton@bournemouth.ac.uk 
grosor y la organización de las hojas y el tercero con compromisos entre el tamaño de hoja, la densidad del tallo y el grosor de la corteza. La densidad del tallo se relacionó fuertemente con varios rasgos, enfatizando su papel clave explicando la variación en las estrategias de historia de vida de las especies de BST. Se observaron diferencias significativas entre grupos funcionales categorizados por filogenia $y$ fenología, mientras que entre formas de vida solo se observaron diferencias para las palmas y guaduas.

Palabras claves: compromisos, estrategias uso de recursos, fenología, forma de vida, grupo filogenético, sequía.

\section{INTRODUCTION}

The classification of plant species in relation to their morphological and life-history characteristics has been a keystone for the development of plant ecology. The use of plant functional types has allowed simplification of the analysis of species distribution in relation to environmental and management characteristics (Chazdon et al., 2010; Laliberté et al., 2010; Enquist \& Enquist, 2011), the relationship between plant functional diversity and ecosystem functioning (Díaz \& Cabido, 1997; Wardle et al,. 2000; Ward et al., 2009; Finn et al., 2013) and the response of ecosystems to global climate change (Fry et al., 2013). Particularly, the use of plant functional traits has been shown to be a promising approach to group species with similar responses to environment factors or with a similar effect on the ecosystem, such as ecosystem engineers and nitrogen fixing plants (Lavorel et al., 2007). The main assumption of trait analyses is that plant trait combinations are limited and that life history strategies are associated with trade-offs that confer fitness under certain environmental conditions at the expense of others (Westoby et al., 2002; Díaz etal., 2004; Wrightetal., 2004; Westoby \& Wright, 2006). For example, Grime (1977) proposed a triangular scheme to describe variation in plant life history strategies according to the relative importance of adaptations to competitive ability, stress and disturbance tolerance. In contrast Westoby (1998) described plant trait variation along a proposed LHS (leaf-height-seed) scheme, in which each axis corresponded respectively to the traits specific leaf area, height at maturity and seed mass, reflecting an accepted trade-off for light and reproductive constraints.

More recently, evaluation of worldwide databases of plant traits has allowed identifying that the major axis of leaf trait variation is the fundamental trade-off between a set of plant attributes that allow rapid acquisition of resources at the expense of longevity, and another set that permits conservation of resources within wellprotected tissues (Díaz et al., 2004; Wright et al., 2004). This trade-off agrees with previous results of Grime et al. (1997), which indicated that the major axis of variation of plants in Great Britain was the adaptive specialization in resource dynamics. In a parallel manner, a wood economic spectrum has been suggested where wood density is a key integrator trait that reflects trade-offs in mechanical support, growth and hydraulic conductivity among species (Chave et al., 2009). However, the generality of these resource use axes describing variation in plant traits has not been completely resolved and global studies have also observed high within-site variation (Wright et al., 2007). Although some general patterns may be identified, trait differentiation results from environment-specific conditions and multiple axes of differentiation may explain community functional diversity (Westoby et al., 2002; Ackerly, 2004; Silvertown, 2004; Hillebrand \& Mathiessen, 2009). Considering that the data analyzed to date represents only a portion of the wide array of ecosystems found in nature, further studies in a wider range of ecological communities are required.

In tropical forests, the gradient of resource use variation in plant leaf and stem traits has 
been related to specific light requirements and performance. Shade intolerant species tend to have higher growth rates, lower seedling survival and shorter lived and low mass density leaves compared to shade tolerant species (Poorter \& Bongers, 2006). Wood anatomical traits on the other hand have been found to relate to light gradients and plant stature and to influence growth and survival in the field (Kraft et al., 2010; Poorter et al., 2010; Wright et al., 2010). These relationships, however, can vary depending on the climatic conditions of the forest. For example, Wright \& Westoby (2002) found that the magnitude of the relation between leaf lifespan and leaf mass per area is different in species of dry sites compared to wet. Likewise, in Bolivia Poorter \& Kitajima, (2007) found differences in carbohydrate storage related to seedling survival between shade-tolerance groups in moist forests but not in the dry forests. Furthermore, a shift in the importance of leaf functional traits that determine plant performance has been observed to occur in dry forest compared to wet, from attributes that determine growth and survival to those that improve growth under light or shade conditions (Poorter, 2009). Light availability in dry forest increases considerably during the dry season generating irradiance levels in the understory several times higher than those observed in wet forests (Lebrija-Trejos et al., 2009), suggesting that there may be factors other than light availability that better describe plant trait variation in this ecosystem compared to wet forests.

Water availability, in addition to light gradients, has being suggested as a major driver of plant variation in tropical forests (Poorter, 2005). Drought tolerance influencing plant communities is especially important in dry forests, which are characterized by three or more months of severe drought during the year (Mooney et al., 1995). In these forests, plant species possess characteristics that allow them to cope with water shortage and that can be segregated along an axis going from drought avoidance to drought resistance (Pineda-Garcia et al., 2013). Deciduous species, characterized by a drought avoidance strategy that allows them to reduce water loss, have been found to be more efficient at water transport and carbon gain than evergreen species (Markesteijn et al., 2011) and to experience lower herbivory rates (Pringle et al., 2010). However, they have also been shown to be more vulnerable to drought-induced embolism (Choat et al., 2005). In contrast, drought tolerant species have developed characteristics like deep roots and tough tissues that allow them to function under low soil and plant water potentials (Ackerly, 2004; Poorter \& Markesteijn, 2008). Drought related adaptations have also been observed in specific life forms or phylogenetic groups. This is the case of lianas, an important structural component of Neotropical forest that have shown high densities in dry forests (Gentry, 1995) and for which higher drought resistance has been hypothesized without consistent results (Schnitzer \& Bongers, 2002; Van der Sande et al., 2013). Lianas have also shown lower specific leaf area and assimilation rates than trees in lowland forest, supporting the view that classification based on plant life-forms can help to simplify functional diversity of this ecosystem (Santiago \& Wright, 2007). The family Fabaceae, which is highly dominant in seasonal dry forest, is also characterized by a group of traits that favor establishment in dry conditions such as compound leaves, high $\mathrm{N}$ leaf content and low specific leaf area and have been considered a distinct functional group in this ecosystem (Powers \& Tiffin, 2010).

The relative importance of shade and drought tolerance in explaining the variation in functional traits of tropical dry forest species is still unresolved. A decoupled adaptation of plant traits to both factors has been suggested in tree species of dry and moist tropical forest of Bolivia, where shade tolerance was related mainly to variation in leaf resource economy traits (Poorter, 2009), whereas drought tolerance was strongly related to leaf organization, deciduousness and to stem and root traits (Poorter \& Markesteijn, 2008; Markesteijn \& Poorter, 2009). In agreement, an orthogonal variation among both leaf and stem traits has been 
observed in an extensive sample of Neotropical wet forest species (Baraloto et al., 2010; Fortunel et al., 2012). On the contrary, strong associations between stem and leaf traits have been observed in seasonally dry forests species in Argentina (Easdale et al., 2007). Mass investment in leaf and stem have also been related to hydraulic conductivity, which has been observed to strongly associate with a coordinated tolerance of trees in this ecosystem to shade and drought (Markesteijn et al., 2011). No further studies have been conducted in dry forests to test these relationships and there is therefore a need for further research on the functional ecology of this ecosystem (Chatuverdi et al., 2011), especially considering the wide-range environmental conditions where these forests are found throughout America (Gentry, 1995).

In Colombia, seasonally dry tropical forests are one of the most threatened ecosystem and only $3.7 \%$ of the original cover remains in a fragmented distribution (Garcia et al., 2014). This scenario has increased the research efforts on these forests and the information available on their floristic composition has increased considerably in recent years (Pizano et al., 2014), however studies on the functional ecology of the plant community are still scarce. Effective conservation and restoration of these forests require a comprehensive knowledge of the environmental factors that influence plant trait variation, which in turn determine the resilience of this ecosystem to drivers of environmental change, such as global warming and reduced precipitation.

This study analyzed the relationships between plant traits in a set of 113 woody species of seasonally dry tropical forests in a region of the Colombian Caribbean to test the hypothesis that leaf and stem traits are coordinated in the plant community of this ecosystem and potentially confer tolerance to both drought and shade tolerance. Additionally, we tested the adequacy of a priori plant functional classifications commonly used for SDTF describing plant variation in these forests.

\section{METHODS}

\section{Study area}

The research was conducted in the Totumo region in the Caribbean coast of Colombia. The landscape in the region is heterogeneous and the main land cover type is pastures for cattle. Other land cover types include shrubland and secondary forest derived from abandoned agricultural fields and pastures, forest fragments and cultivated crops (mostly maize and yuca). The climate is characterized by a mean annual temperature between 24 and 27.5 ${ }^{\circ} \mathrm{C}$ with maximum temperatures of $38{ }^{\circ} \mathrm{C}$ (IGAC, $2004 ; 2008)$. Mean annual precipitation is around $900 \mathrm{~mm}$ distributed in a rainy season from April to early December, with a decrease in precipitation during June and July, followed by a 5 month dry season. Forests in the region have been described as Neotropical dry forests (Gentry, 1995), with a mean canopy height of $20 \mathrm{~m}$ (pers. obs.). The most species diverse families reported for the region are Fabaceae, Malvaceae and Bignoniaceae and some of the most abundant genera are Cordia, Coccoloba, Senna, Paullinia, Trichilia, Acacia and Cynophalla (Rodríguez et al., 2012).

\section{Study species}

A total of 113 species were included in the study on the basis of vegetation assessments conducted during 2011 in three sites that offered secondary tropical dry forest of different ages and similar patterns of land use. The Regional Natural Park El Ceibal-Mono Tití $\left(10^{\circ} 37.19^{\prime} \mathrm{N}, 7^{\circ} 14.28^{\prime}\right.$ W) and the Regional Natural Park Los Rosales $\left(10^{\circ} 37.78^{\prime} \mathrm{N}, 75^{\circ} 12.56^{\prime} \mathrm{W}\right)$ correspond to two privately owned farms, located in the departments of Atlántico and Bolívar respectively, that possess forest fragments of nearly 300 ha, whereas the Protective Forest Reserve El Palomar (10 45.39' $\left.\mathrm{N}, 75^{\circ} 09.22^{\prime} \mathrm{W}\right)$, located in the department of Atlántico, is composed of 19 privately owned farms that possess three fragments of forest of 
approximately 60 ha each and others of smaller size (>10 ha). The assessments included three types of forest cover that were differentiated on the basis of satellite imagery and field observations, namely early, intermediate and late secondary forests. Cattle pasture is common in the secondary vegetation at the three sites, although it is limited by the topography, and fire spreading from agricultural areas occurs occasionally.

The species selected were those that contributed to $70 \%$ of the basal area of at least one of 12310 $x 10 \mathrm{~m}$ plots, fairly distributed among the three forest types and sites, where all individuals with a $\mathrm{DBH}>2.5 \mathrm{~cm}$ were identified and recorded. This approach follows definition by Cornelissen et al. (2003) of the most abundant species in a community based on measures of biomass contribution, assuming that this proportion of the species provides a good representation of the plant community in the region. For this study however basal area was used as a proxy for biomass. Nomenclature follows that of the Missouri Botanical Garden (Tropicos 2013).

\section{Plant trait selection and measurements}

Functional traits are the characteristics of an organism that are considered relevant to its response to the environment and/or effect on ecosystem function (Díaz \& Cabido, 2001). Plant traits include various life history, morphological, physiological and biochemical characteristics of an organism. In practical terms, they have been divided into soft and hard traits; the former includes those that can be easily measured in the field or by simple laboratory procedures, while the latter require more complex methods or long periods of time (Cornelissen et al., 2003; Weiher et al., 1999). For this study, we selected traits based on two criteria, that they were reported in the literature to be correlated to survival and growth performance of plants under limiting water and light conditions, and that they were feasibly measured in field conditions. The traits selected correspond to soft traits that are expected to be sufficiently fixed to characterize species despite intra-specific variability.

Field collections were made from June to September 2011. Leaf characteristics were measured in 5 individuals for most species (i.e., 86 of 113) following the recommendations of minimum sample size of Cornelissen et al. (2003). For rare species, we were only able to measure leaf characteristics in 4 individuals (10 species) or 3 individuals (17 species). Variation associated with the development stage and the effects of light environment were reduced by selecting healthy mature leaves from the outer leaf layer of the crown that were exposed to full sunlight at least during a few hours of the day. This last criterion was not considered for species whose individuals were found primarily in the understory. Fully expanded leaves without epiphylls and significant herbivore damage were collected, including the corresponding petioles. The leaves were stored in sealed plastic bags with a wet tissue and maintained in the shade to avoid dehydration until measurement; all measures were taken on the same day of collection.

For each individual 5 leaves were measured for fresh mass, lamina thickness and force to punch. Due to the complexity in practical terms of measuring all leaflets in compound leaved species, especially for legumes with highly dissected leaves, we measured these traits in individual leaflets of average size, under the assumption that these provide a good representation of lamina tissue. Lamina thickness (LT) was measured with a digital calliper avoiding visible primary and secondary veins in two different sections of the lamina. The force-to-punch a leaf was measured using a push and pull gauge (rod diameter $3.18 \mathrm{~mm}$, Chatillon 516-1000, AMETEK TCI Division, Chatillon Force Measurement Systems) following Pringle et al. (2010). Although the use of punch tests has been criticized (Sanson et al., 2001) as it does not actually measure leaf toughness directly, the results obtained with this technique are consistent with 
those using other shearing instruments as long as the diameter of the punch is specified and the measure is corrected for the length or thickness of the leaf (Kitajima \& Poorter, 2010; Onoda et al., 2011). It is also a valid technique for comparative studies that do not analyze in detail biomechanical properties. The rod head was therefore positioned to avoid primary and secondary veins and measures were taken in two positions of the leaf blade. The mass at the moment of penetration of the leaf was converted to punch force by converting grams to newtons and dividing by the rod circumference (Fp, $\mathrm{N} . \mathrm{mm}^{-1)}$. The use of the circumference instead of rod area to normalize the data has been recommended to reduce sensitiveness to the size of the punch diameter (Onoda et al., 2011). Fp was subsequently divided by the lamina thickness to calculate the specific force-to-punch (Fps, N.mm-2).

Additionally, a digital picture was taken of each leaf after placing it on a white background between two sheets of glass and marking the scale. The pictures were analyzed with pixelcounting software to calculate the area of the lamina and the petiole (Rasband, W.S., Image), U. S. National Institutes of Health, Bethesda, Maryland, USA). Leaf area (LA) considered the area of the lamina blade without the petiole; for compound leaves leaf area was calculated by multiplying leaflet areas by the mean number of leaflets. Compoundness was recorded in three states: simple leaves, pinnate and bipinnate. Species were assigned to one of two leaf habits, deciduous or evergreen, based on field observations, local interviews and literature records. Although deciduous species have been shown to vary in the timing and length of the leafless period no distinction was made as no detailed information was available for all species.

Seeds were collected for 46 species and the number of individuals sampled varied according to availability ( 1 individual for 17 species, 2 for 15 species, 8 for 3 species, 4 for 4 species and 5 for two species) and from each individual at least 10 seeds were measured for dry biomass. Leaves, leaflets and seeds were dried for a minimum of $48 \mathrm{~h}$ at $60-70{ }^{\circ} \mathrm{C}$ to record dry mass. Samples were dried using a gas oven at the installations of the University of Atlántico, Colombia, were they were located approximately 70 $\mathrm{cm}$ over the oven on an aluminum table and were protected using a cardboard sheet. Temperature was constantly monitored using laboratory thermometers. To assure that samples had lost all water content, a few samples were weighed, placed again inside the room and weighed a few hours later to check if the dry mass continued decreasing. If this was the case all the material was dried for additional hours, until a constant dry mass was obtained. Based on these measurements the following variables were calculated: leaf dry matter content $($ LDMC $=$ dry mass per unit of fresh mass) and specific leaf area (SLA in cm2.g-1 = total leaf area / leaf dry mass) and seed mass (SM in g).

Stem density (SD) was measured in five individuals for most species (79 of 113) as the dry weight ( $\mathrm{g}$ ) per unit volume $(\mathrm{cm} 3)$ of stem samples. For rare species, measures were taken from 4 individuals (16 species) or 3 individuals (18 species). DBH of individuals sampled varied among species and life form. Source individuals varied in range by less than $10 \mathrm{~cm}$ in $85 \%$ of the liana species (12 of 14 ), $80 \%$ of the palms and bamboos (4 of 5) and $62 \%$ of the trees species (59 of 94). For the remaining species, source individuals $\mathrm{DBH}$ varied in range by more than $20 \mathrm{~cm}$, and for 18 species of trees this value was higher than $40 \mathrm{~cm}$. Samples were collected by cutting a section of the trunk, approximately $7 \mathrm{~cm}$ length $\times 1-2 \mathrm{~cm}$ depth, covering bark, alburnum and for some species duramen tissue. In the case of relatively soft-stemmed species, such as Bursera simaruba, Ceiba pentandra and Hura crepitans an increment borer was used to take a stem sample for analysis. For lianas and plants with stem diameters $>6 \mathrm{~cm}$ and height $>4 \mathrm{~m}$, the samples were taken at approximately $1.3 \mathrm{~m}$ height. For plants with thin main stems (diameter $<6 \mathrm{~cm}$ ) or smaller than $4 \mathrm{~m}$ height, a section was cut at approximately one third of the stem height. Green volume was calculated using the water displacement method (Chave, 2005), 
by immersion of samples into a container of water loaded on a top-loading electronic balance, where volume was read as the mass of the displacement water. Bark thickness (BT) was measured in stem sections using a digital caliper; for some of the species measures were taken in dried samples and the values may therefore be relatively low owing to tissue contraction. For palms and bamboos we measured the width of the cortex and epidermis. Samples were kept in a cool place until oven-dried for at least $48 \mathrm{~h}$ at $60-70{ }^{\circ} \mathrm{C}$, as previously described for leaf samples, and dry mass recorded.

Height, estimated visually by the field team, and crown exposure of each individual, were also recorded. Crown exposure index (CE) values were obtained through visual assessment following Poorter \& Kitajima (2007): CE is assigned a value of 1 if the tree does not receive any direct light, 2 if it receives lateral light, 3 if it receives overhead light on part of the crown, 4 when it receives full overhead light on the whole crown and 5 when it has an emergent crown that receives light from all directions. Considering that a species could potentially be found in different light environments during different growth stages, the highest value of crown exposure recorded in the field was used for analysis.

Spinescense records follow the categorical classification of Cornelissen et al. (2003): 0) no spines, thorns or prickles; 1) low or very local density of soft spine equivalents of $<5 \mathrm{~mm}$ length; 2) high density of soft spine equivalents or intermediate density of spine equivalents of intermediate hardness- or else low density of hard, sharp spine equivalents $>5 \mathrm{~mm}$ length; 3) intermediate density of hard, sharp spine equivalents $>5 \mathrm{~mm}$ length; 4 ) intermediate density of hard, sharp spine equivalents $>20 \mathrm{~mm}$ length and 5) intermediate density of hard, sharp spine equivalents $>100 \mathrm{~mm}$ length.

\section{Data analysis}

Traits measured in the field presented two levels of sampling, species and individual trees. To explore which of these levels was the largest source of variation, a linear mixed effect model was fitted to the data considering each level of sampling as a random factor. Variation between individuals in seed mass only considered a few species, as for most species all the seeds were collected from one individual. Traits that did not meet the assumptions of the analysis were transformed by means of the natural logarithm. Significance of each level of grouping (species, individuals) was analyzed by means of simple ANOVAs or Kruskall-Wallis test on aggregated data to account for the unbalanced sampling effort.

Species-specific trait values were calculated using an arithmetic mean and the resulting variables were tested for normality using the Shapiro-Wilk test. Traits that differed from a normal distribution were transformed by means of the natural logarithm to reduce skewness. Relationships between the traits were analyzed by calculating multiple correlations using the Pearson's coefficient. Because of very high differences between maximum and minimum values for LA, Fp and Fps, these variables did not fit normal distribution after transformation and correlations were analyzed using Spearman's coefficient.

A principal components analysis was carried out on the correlation matrix to explore the relationships between traits and the distribution of species along the reduced ordination axis. SLA, LA, LT, Fps and BT were transformed before the ordination to reduce skewness and Fp was excluded due to high correlation with Fps. Considering the high number of missing cases for SM, the analyses were performed using all the species sampled and excluding the seed variable. Missing values were replaced by the mean in two cases, bark thickness for Hura crepitans and Ceiba pentandra. Compoundenss and spinescense were considered as quantitative ordinal variables. The relationship between SM, maximum height and CE and the scores of the first three principal components were analyzed by means of correlation tests. For these analyses, only those species with data from 10 
or more individuals of maximum height and CE were considered to avoid estimations from a low sampling number.

To test for differences between functional groups three a priori classifications were considered; species were classified according to leaf phenology, life form and phylogenetic clade. In terms of phenology, species were classified as evergreen or deciduous and no discrimination was made between different levels of deciduousness considering the heterogeneous sources of information. Species were categorized as one of the following life forms: trees, lianas, palms or bamboos. This study included 14 species of lianas and 6 of palms and bamboos that were an important structural element of the forest in the region. For phylogenetic clade four groups were considered following the AGP III system (2009): monocots (commelinids), eudicots, Fabaceae as a special case of eudicots, and magnoliids.

To test for differences between functional groups an analysis of variance using distance matrices was conducted using the function adonis within $\mathrm{R}$ (version 2.15.1, R Core Team 2012); dissimilarity between pairs of species was calculated as the Euclidean distance and the significance of the statistic $R$ was assessed with 200 permutations. In addition, differences in individual functional traits between the groups of a priori classifications were tested by means of Student's t test; the Wilcoxon signed-rank test was used for variables that were not normalized even after transformation. Categorical data was analyzed by means of the chi-squared test. For these analyses only Fabaceae and Eudicots were considered among phylogenetic groups and lianas and trees among life forms, due to the small number of samples for the remaining functional groups. These analyses were conducted using the packages vegan, cluster and fpc (Maechler et al., 2012; Oksanen et al., 2012; Hennig, 2014) within R (version 2.15.1, R Core Team 2012).

\section{RESULTS}

Plant traits recorded in the field varied widely among the species (Table 1). Leaf area (LA) showed the highest variation with values varying by four orders of magnitude. This can be explained by the high leaf area of palms and other species included in the study such as Sterculia apetala, Cecropia peltata and Cavallinesia platanifolia. Other traits that showed high variation among values were specific leaf area (SLA; one order of magnitude), force to punch (Fp; one order of magnitude) and specific force to punch (Fps; three orders of magnitude). Leaf dry matter content (LDMC) and stem density (SD) showed especially low minimum

Table 1. Summary statistics for eight functional traits of a set of 113 species of seasonally dry tropical forests. Leaf dry matter content (LDMC), leaf thickness (LT), specific force to punch (Fps), leaf area (LA), specific leaf area (SLA), stem density (SD), bark thickness (BT) and seed dry mass (SM).

\begin{tabular}{lccccc}
\hline & Min & Max & Mean & $\sigma$ & Median \\
\hline LDMC $\left(\mathrm{g} \cdot \mathrm{g}^{-1}\right)$ & 0.08 & 0.61 & 0.32 & 0.10 & 0.33 \\
$\mathrm{LA}\left(\mathrm{cm}^{2}\right)$ & 6.66 & 47338.00 & 996.30 & 5777.39 & 67.11 \\
$\mathrm{SLA}\left(\mathrm{cm}^{2} \cdot \mathrm{g}^{-1}\right)$ & 67.96 & 589.78 & 198.98 & 85.57 & 186.13 \\
$\mathrm{SD}\left(\mathrm{g} \cdot \mathrm{cm}^{-3}\right)$ & 0.13 & 0.85 & 0.54 & 0.14 & 0.57 \\
$\mathrm{LT}(\mathrm{mm})$ & 0.06 & 0.58 & 0.19 & 0.07 & 0.18 \\
Fps $\left(\mathrm{N} \cdot \mathrm{mm}^{-2}\right)$ & 0.36 & 536.32 & 34.79 & 79.50 & 11.89 \\
BT $(\mathrm{mm})$ & 0.26 & 7.30 & 2.89 & 1.50 & 2.67 \\
SM $(\mathrm{g})$ & 0.00 & 15.96 & 0.76 & 2.41 & 0.05 \\
\hline
\end{tabular}


values, which correspond respectively to the cactus species Pereskia guamacho that possess very succulent leaves, and to the species C. platanifolia common in dry forests and characterized by a water storage trunk.

Interspecific differences were the major source of variation for all plant traits (Table 2) and the two levels of sampling, species and individuals trees, were significant for all traits $(P<0.001)$. For LA, LDMC, Fps, SD and seed dry mass (SM) the percentage of variation explained by species differences was high (71-96\%), whereas for SLA and bark thickness (BT) an important percentage of variation was explained by differences between individuals or remained unexplained. In relation to leaf organization, $62 \%$ of the species included in the study had simple leaves, $28 \%$ pinnate leaves and $10 \%$ bipinnate leaves. For spinescense most of the species did not possess spines (85\%) and when present, high variability was observed, from very low densities to high densities of hard spines (e.g. Bactris guianensis).

Significant correlations were found for all plant traits (Table 3). LDMC was negatively correlated

Table 2. Percentage of variance explained by species and individuals in a set of eight functional traits. Both levels of variation were significant for all traits. Based on 113 species and 523 individuals, except seed mass (49 species, 101 individuals), stem density (109 species, 500 individuals) and bark thickness (109 species, 477 individuals).

Leaf dry matter content (LDMC), leaf thickness (LT), specific force to punch (Fps), leaf area (LA), specific leaf area (SLA), stem density (SD), bark thickness (BT) and seed dry mass (SM).

\begin{tabular}{lcccccccc}
\hline & LDMC & LT & Fps & LA & SLA & SD & BT & Seed \\
\hline Species & 68.90 & 72.71 & 71.75 & 91.68 & 52.38 & 77.58 & 52.92 & 95.39 \\
Individual & 12.00 & 20.13 & 17.09 & 4.41 & 30.10 & - & - & 3.23 \\
Residual & 19.1 & 7.2 & 11.2 & 3.9 & 17.5 & 22.4 & 47.1 & 1.4 \\
\hline
\end{tabular}

Table 3. Pair-wise relationships amongst 10 functional traits of 113 tropical dry forest species. Values indicate Pearson's coefficient for relationships between LDMC, SLA, SD and BT; for all other relationships values indicate Spearman's coefficient. For seed mass analysis considered 45 species. Significant correlations at $P<0.001$ are indicated in bold, in bold and italics $P<0.05$. For trait abbreviations and units see Table 2, except Maximum height- Mheight $(\mathrm{m})$ and Compoundness- Comp.

\begin{tabular}{lcccccccccc}
\hline & LDMC & LA & SLA & SD & LT & Fps & BT & Spines & Comp. & Seed \\
\hline LDMC & & & & & & & & & & \\
LA & 0.05 & & & & & & & & & \\
SLA & $\mathbf{- 0 . 3 9}$ & -0.08 & & & & & & & & \\
SD & $\mathbf{0 . 5 4}$ & $\mathbf{- 0 . 2 1}$ & -0.16 & & & & & & & \\
LT & $\mathbf{- 0 . 3 5}$ & 0.02 & $\mathbf{- 0 . 3 3}$ & $\mathbf{- 0 . 2 4}$ & & & & & & \\
Fps & $\mathbf{0 . 4 1}$ & 0.14 & $\mathbf{- 0 . 6 5}$ & $\mathbf{0 . 2 2}$ & 0.28 & & & & & \\
BT & -0.06 & 0.16 & -0.1 & $\mathbf{- 0 . 2 4}$ & 0 & -0.04 & & & & \\
Spines & 0.05 & 0.03 & 0.15 & -0.07 & -0.09 & 0 & -0.12 & & & \\
Comp. & 0.34 & 0.4 & 0.13 & 0.06 & $\mathbf{- 0 . 4 9}$ & -0.13 & 0.07 & 0.14 & & \\
Seed & 0.28 & $\mathbf{0 . 6 2}$ & $\mathbf{- 0 . 4 8}$ & $<0.01$ & -0.05 & $\mathbf{0 . 5 8}$ & 0.19 & -0.05 & 0.28 & \\
Mheight & -0.11 & 0.23 & -0.01 & $\mathbf{- 0 . 3 5}$ & 0.09 & 0.12 & 0.23 & -0.03 & -0.05 & 0.11 \\
\hline
\end{tabular}


with SLA $(P<0.001)$ and leaf thickness $(\mathrm{LT} ; P<$ $0.001)$ and positively correlated with $\mathrm{SD}(P<$ 0.001), Fps $(P<0.001)$ and compoundness $(P<$ 0.001). Other significant correlations were found between SM, LA, SLA and Fps. Considering that the high values of LA and SM observed in palms could influence the relationship between these traits, the analysis was rerun by removing this group of plants, however similar values to those observed when considering the whole data set were obtained. Results suggest that species with higher SM are characterized by larger leaves, low SLA, and high Fps and that species with high SD are also characterized by high LDMC and Fps, and less strongly by low BT and LT.

The first three components of the PCA explained $25 \%, 24 \%$ and $15 \%$ of plant trait variation (Table 4). The first component was highly correlated to LDMC, Fps and SLA, and more weakly to SD, whereas the second component was highly correlated with leaf thickness and compoundness, and more weakly to SLA (Table 4). Based on these results species with high investment in leaf and stem tissues were clustered on the negative side of the first axis of the ordination plot and species with compound and thin leaves on the positive side of the second axis (Figure 1). The third component was highly negatively correlated to LA and with a lower magnitude to SD, bark thickness and compoundness. Maximum height, SM and crown exposure (CE) were correlated with the species coefficients along the third component (Figure 2), SM was also correlated with species coefficient along the first component and no significant relationships were observed with the coefficients of the second component of the ordination.

Significant differences were found between legumes (Fabaceae) and the remaining Eudicots by means of an analysis of similarities $(F=13.7$, df $1, P=0.005)$. Legumes were located on the top of the second axis and were characterized by compound leaves, low LT and high SLA (Figure $1 \mathrm{~b}$ ). These results were confirmed by significant differences in the analysis of individual plant traits, with legumes presenting higher LDMC and SLA and lower Fps and LT than the remainder Eudicots (Table 5). Considering leaf phenology, significant differences were also found by means of the analysis of similarities ( $F=7.2$, df $1, P=0.005)$. Deciduous species presented significantly lower LDMC, and Fps and higher SLA and BT than evergreen, as well as a higher number of compound-leaved species (Table 5). No differences were found between life forms $(F=1.7$, df $1, P=0.13)$, as lianas covered the same range of trait characteristics as trees (Figure 1, Table 5); bamboos and palms on the other hand were located in the extreme right of the distribution in the first axis, reflecting their high LDMC and Fps.

Table 4. PCA components (variance explained) and loadings of plant traits for a set of 113 species of SDTF. For trait abbreviations and units see Table 1, except Compoundness- Comp.

\begin{tabular}{lccccccccc}
\hline & LDMC & SD & Spines & Comp. & LA & SLA & LT & Fps & BT \\
\hline PC1 $(24.5 \%)$ & -0.53 & -0.37 & -0.01 & -0.03 & -0.17 & 0.52 & 0.00 & -0.53 & 0.07 \\
PC2 (23.9\%) & 0.32 & 0.30 & 0.11 & 0.52 & -0.04 & 0.34 & -0.57 & -0.24 & -0.16 \\
PC3 $(15.3 \%)$ & -0.01 & 0.46 & -0.20 & -0.35 & -0.71 & 0.01 & 0.06 & -0.08 & -0.34 \\
PC4 (12.7\%) & 0.12 & 0.06 & -0.74 & 0.06 & -0.07 & -0.10 & -0.15 & -0.14 & 0.61 \\
\hline
\end{tabular}




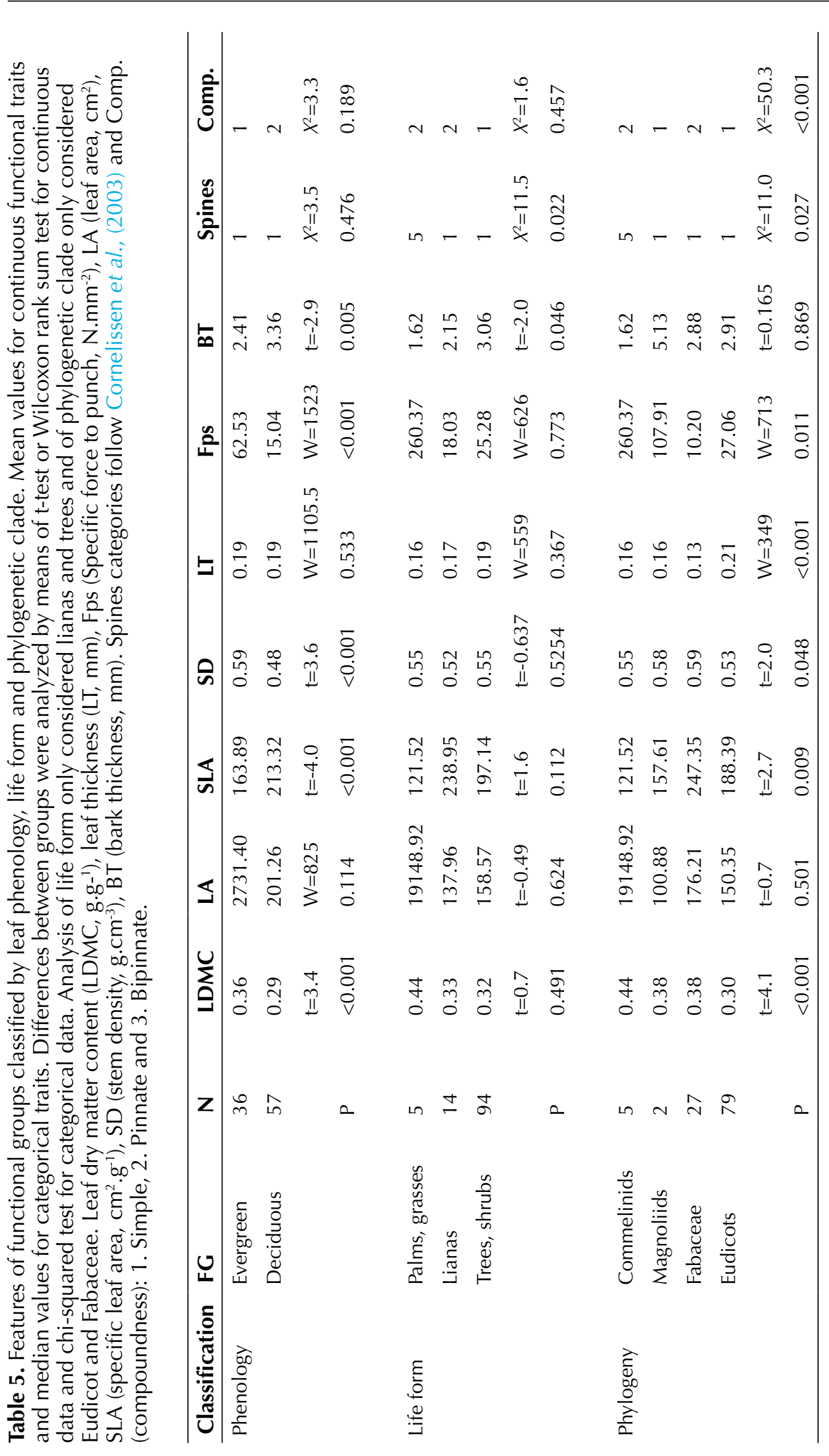



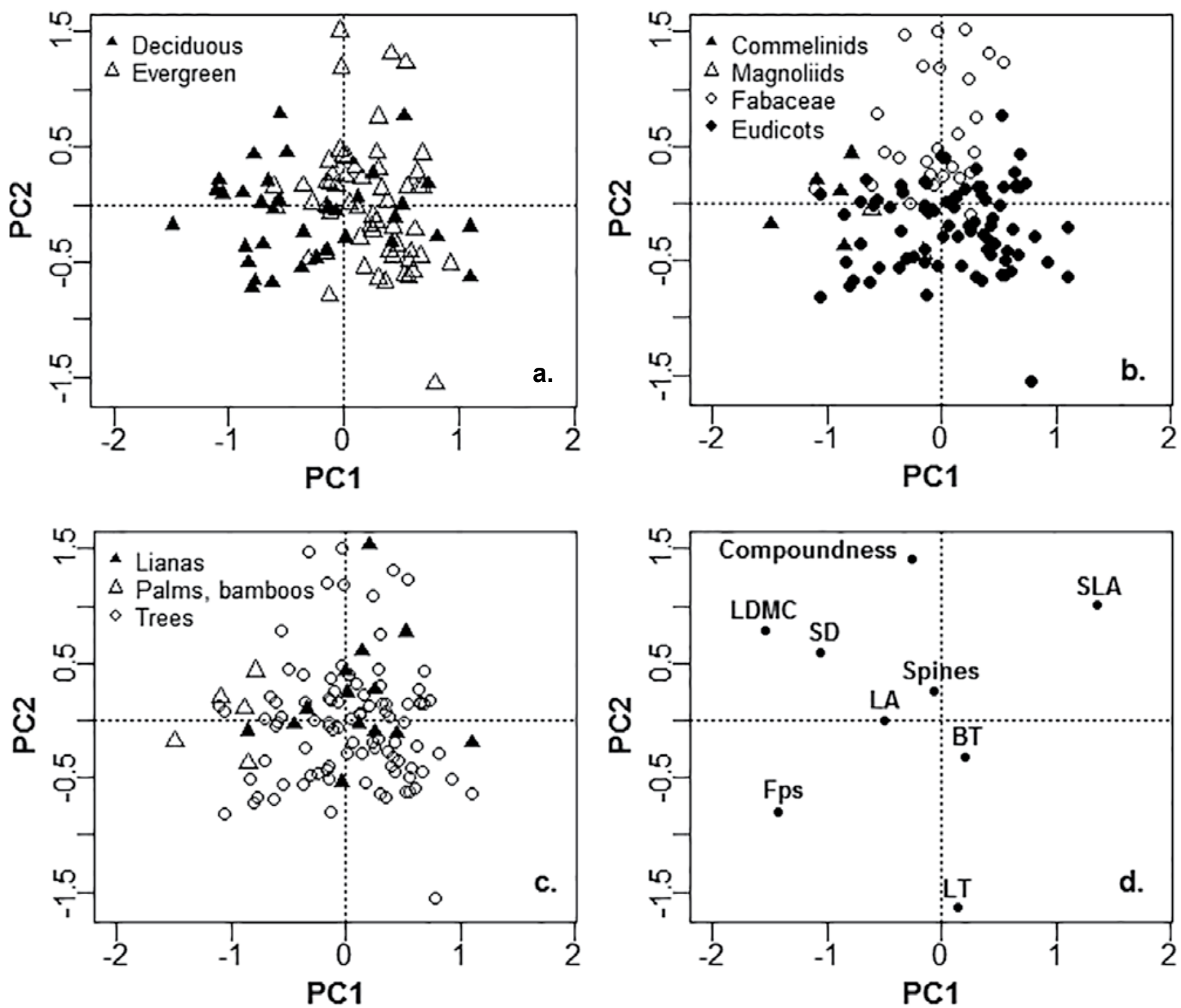

Figure 1. Principal component analysis biplot of functional trait data for 113 species of SDTF. Different symbols indicate grouping by different functional classifications: a.) leaf phenology, b.) phylogenetic clade, c.) life form and d.) Scores of plant functional traits on the first and second axis. 

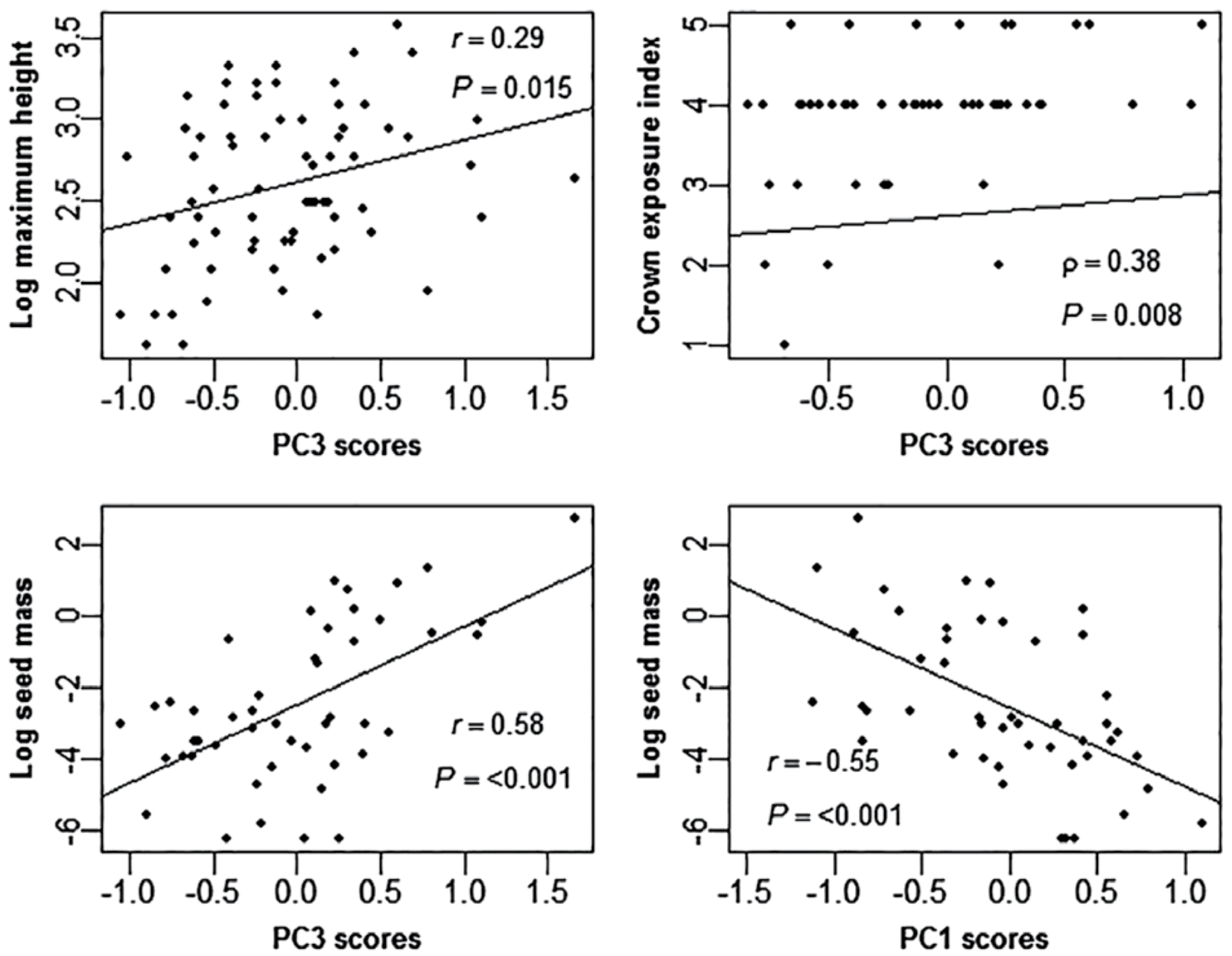

Figure 2. Scatterplot of significant relationships between plant functional traits and species scores along the first and third axes of a principal component analysis. Pearson $(r)$ and Spearman $(\rho)$ coefficients and significance levels are given. $\mathrm{N}$ is 68 species for maximum height, 46 for crown exposure index, and 45 for seed mass. The continuous line indicates the straight line of best fit.

\section{DISCUSSION}

The variability of morphological traits among plant species was very high as expected from the numerous and diverse sample of woody plants included in the study. The assumption that interspecific variation was higher than intraspecific variation was confirmed by the results and a great percentage of the variation in functional traits was explained at the species level, with the exception of specific leaf area (SLA) and bark thickness (BT). The measurement of SLA is subject to high natural variability in relation to the light environment, leaf age and sampling errors (Wilson et al., 1999); factors that may not have been completely controlled in this study. In the case of BT the high percentage of variation that remained unexplained could be partially related to differences in individual tree diameter, which have been shown to strongly influence this trait (Paine et al., 2010) and varied by more than $10 \mathrm{~cm}$ for one third of the tree species. 


\section{Relationships among stem and leaf traits}

The strong negative correlations observed provide evidence of coordination between stem and leaf traits that are reported to determine shade and drought tolerance and suggest that trade-offs are occurring. These results support the hypothesis that functional trait variation of woody species in dry forests can be explained better in terms of acquisitive traits that allow high resource use under high light or water availability conditions versus conservative traits that provide tolerance to both shade and drought (Markesteijn et al., 2011; Sterck et al., 2011).

The first axis of the ordination, related to leaf density and toughness, was characterized by the strong negative relationship between SLA, Fps and LDMC. This axis of variation has also been identified for other lowland forests as part of the shade tolerance strategy where species with tougher and denser leaves were also characterized by longer lifespan, lower palatability, low sapling relative growth rate and high survival (Kitajima \& Poorter, 2010). The second component was related to leaf organization and thickness, traits that can favor both growth and drought tolerance. Compound leaves have been suggested to decrease branching and allow rapid increases in vertical growth for both shade-tolerant and pioneer species (Malhado et al., 2010). They have also been associated to higher $\mathrm{C}: \mathrm{N}$ ratios compared to simple leaves, which are related to lower energetic costs with no detrimental effect in herbivory defense (Warman et al., 2010). Leaf thickness on the other hand has been observed to vary independently of leaf toughness and LDMC and was related to leaf lifespan in woodlands of Australia (Wright \& Cannon, 2001), although this relationship was not observed in moist forests of Bolivia (Kitajima \& Poorter, 2010).

Leaf area was not correlated with any other leaf trait but it was negatively related to SD, determining the third axis of trait variation. This link between SD and LA has been explained by plant hydraulics, as species with lower wood density have on average higher hydraulic conductivity and will be able to transport more water to the leaves (Wright et al., 2007). A significant negative relationship between these two traits has also been observed in multi-species analysis of lowland Neotropical forests (Malhado et al., 2009; Baraloto et al., 2010). Moreover, the significant correlations between traits observed in this study agree with the predicted relationships of plant traits in low rainfall locations provided by Baraloto et al. (2010), where they expected: 1) a decoupling of leaf area from leaf toughness accompanied by a lower probability of herbivore damage risks to tissue, and 2) a stronger association between leaf area and stem economics because of increased risk of cavitation with increased transpiration surface.

The third axis was also weakly correlated with BT and compoundness, reflecting their positive correlation with SD and LA. In terms of leaf organization, there was a tendency for compound leaves to have higher leaf size and these differences were significant when treating compoundness as a factor in an independent analysis; specifically pair-wise comparisons showed that simple leaves had a smaller area than pinnate leaves. Differences in LA between simple and compound species have not been documented and previous analyses have only considered leaflet size for comparisons between them (Warman et al., 2010); although a consistent positive relationship between leaf and leaflet area has been observed (Patiño et al., 2012). Nevertheless, a higher investment in biomass has been observed in compound leaved compared to simple leaved species (Niinemets et al., 2006), which would favor leaf expansion without increasing photosynthetic area prone to desiccation, allowing compound species to exploit high light availability but also to tolerate drought. On the other hand, the negative relationship between BT and SD could be explained by a lower need of denser stems 
for external herbivory defense (as suggested by Paine et al., 2010) and fire resistance (Brando et al., 2012).

Stem density was correlated strongly with the first and third axes, and to a lesser extent to the second, underlying its key role in dry forest species variation. SD was also negatively correlated with maximum height, supporting the trade-off between rapid growth versus high survival and investment in structural tissues (Wright et al., 2010). Furthermore, wood density and maximum height have been identified as the principal traits that determine species growth rate and its variation in relation to changes in light availability and size (Rüger et al., 2012).Wood density has also been shown to determine species drought tolerance by its close relationship to stem hydraulic conductivity and vulnerability to cavitation (Markesteinj et al., 2010). In relation to traits associated with the leaf economic spectrum, the strong positive relationship between SD and LDMC found in this study agrees with observations in other tropical dry forests (Poorter \& Markesteinj, 2008; Markesteinj et al., 2011); species with a conservative use of resources present a higher mass investment in plant tissues including leaves, stem and roots at the expense of a more efficient hydraulic system. In the these studies however a strong relationship between SD and SLA was also observed, contrary to our results, whereas an independent variation of SLA in relation to $\mathrm{SD}$ has been more common in wet tropical forests (Wright et al., 2007; Baraloto et al., 2010).

\section{Seed size and light environment}

Variation in seed size has been identified as an independent dimension of the ecological strategy of plants, as well as variation in leaf size and in traits related to the leaf economics spectrum (Wright et al., 2007). Our results, however, showed high correlation of seed mass with species scores on the first axis of variation that relates to the dry mass investment in leaves and stem, suggesting that dry forests species with high individual seed mass (SM) also have a tendency for high cost leaves. In agreement, higher seed mass has been observed in shade tolerant compared to shade intolerant species of dry forest in India (Khurana et al., 2006).

The strong relationship observed between SM and LA determined the former's correlation with the third axis of the ordination analysis. This link corresponds with one of the main patterns of specialization identified by Díaz et al., (2004) using a world wide database of temperate ecosystems and agrees with the positive relation between seed size and leaf area, not maximum height, found in moist forests in Panama (Rüger et al., 2012). In contrast, for trees of Amazonian wet forests seed size was related to maximum height and not to leaf area (Wright et al., 2007; Patiño et al., 2012). In seasonally dry forest, wind dispersed species characterized usually by seeds of small size are more abundant than in wet forest (Gentry, 1995; Khurana et al., 2006) and this characteristic could weaken the relation between seed size and maximum height in this ecosystem. On the other hand, the sample we used to analyze relationships with seed size was smaller than for other traits and most of the collection of fruits was conducted during the wet season, so an underrepresentation of fruit dispersed during the dry season could have occurred. It is possible that a larger sample could weaken the relationships observed but it is unlikely that the general pattern would change.

Maximum height and CE are proxies of the vertical position of the species in the forest and these were correlated with the third axis of the PCA, determined by LA and SD. Trees with larger leaves and lower stem density are then expected to be observed in gaps and in higher vertical stratums of these forests. The relationship between the third axis and CE however showed high variation and the pattern observed is better explained as a tendency for trees with low crown exposure to present small leaves, whereas trees with high CE 
show high variation in leaf size. Maximum height and crown exposure (CE) on the other hand did not correlate with the first axis, suggesting that different leaf resource strategies can be present at different light environments. This study however did not consider the regeneration light requirements of the species, which have been observed to relate better to leaf traits than the adult light niche in moist forests, when measured as the maximum height and average adult crown exposure (Poorter, 2007). For example, in tropical forest of Bolivia light-demanding species compared to shadetolerant were characterized by larger leaves as well as larger internode cross-sectional area, longer petioles, and a larger biomass fraction in petioles (Poorter, 2009). Future studies require incorporating measures of the regeneration niche of the species, to test for the consistency of the relationships observed.

\section{Plant functional types}

Classification of species according to leaf phenology and phylogenetic clade revealed different strategies of plant trait coordination. Deciduous species differed from evergreen species in their distribution along the first axis of the ordination and showed a tendency to have an acquisitive use of resources with higher SLA and lower LDMC, Fps and SD. These results agree with studies in other Neotropical seasonally dry forest, where differences in stem density and leaf density, toughness and dry matter content were observed between both leaf habits (Easdale et al., 2007; Pringle et al., 2010; Markesteijn et al., 2011). Timing of leaf shading and extent can vary considerably among species in relation to soil water potential due to differences in stem water content and hydraulic conductivity (Pineda-Garcia et al., 2013). As wood density has been shown to relate closely to both of these traits (Pineda-Garcia et al., 2011; Markestein et al., 2011), we expect that some of this variation has been covered by incorporating this trait in the ordination analysis. However, there was an evident overlap of trait values reflecting the difficulty of classifying species based solely on leaf phenology in agreement with observations by Powers \& Tiffin (2010) and Chatuverdi et al. (2011).

In a complementary manner, phylogeny was an important factor differentiating species along the second axis of variation that considers leaf organization and thickness. Although a broad classification approach was used, our results confirm that Fabaceae is a distinctive functional group that has developed a series of characteristics that favour drought tolerance and could explain their high abundance in this ecosystem (Powers \& Tiffin, 2010). A great proportion of the legumes registered in the area were deciduous and except for one all were compound-leaved, they also presented a lower LT and higher SLA than the remaining Eudicots. Compound species have been related to faster diameter growth rates and lower wood density in wet forests (Malhado et al., 2010), which would allow legumes to take advantage of high light availability conditions. Other studies have found that among tree species of the Amazon, Fabaceae were characterized by thin leaves and high mineral nutrients concentrations, although a wide variation in wood density was observed (Baraloto et al., 2010).

In terms of life forms, classification of species specifically in lianas and trees did not reflect variation in leaf and stem morphological traits. Considering that some of the traits measured are associated with the growth-survival trade-off (Wright et al., 2010), our results agree with other studies in not finding differences in the slope or range of this trade-off between these two life forms (Gilbert et al., 2006). In addition, no differences in physiological and morphological functional traits between lianas and trees were observed at the sapling stage by Van der Sande (2013), although lianas did present lower cavitation resistance and higher hydraulic conductivity than trees. These authors suggested 
that the lack of differences in functional traits between the two life forms could change in later ontogenetic stages when lianas would invest less in stem biomass and more in photosynthetic leaf area, however our results on adult traits did not find differences between them either and both life forms showed a wide trait variability.

\section{CONCLUSIONS}

In agreement with observations in other seasonally dry tropical forests, leaf and stem traits showed strong relationships in the plant community studied, potentially conferring coordinated tolerance to shade and drought. Variation in traits such as leaf dry matter content, leaf thickness and stem density, were highly explained by differences at the species levels, whereas other traits such as specific leaf area and bark thickness were influenced by environmental conditions, characteristics of the source individual and other unmeasured factors. For future studies of the functional ecology of plant communities, we recommend the use of traits with low inter-specific variability or a strict control of differences between source individuals for traits with high inter-specific variability. The three axis of variation identified in this study correspond to independent dimensions of the ecological strategy of plants previously identified, such as the resource economics spectrum and the leaf area and stem density trade-off. In addition, seed mass and measures of the adult light requirements showed significant relationships with these axes, supporting evidence for coordination at the whole-plant level. Analysis of plant traits between functional groups classified by phylogeny and leaf phenology confirmed that legumes and deciduous species are distinct groups in this ecosystem, whereas classification by life form only showed differences among groups of species for palms and bamboos.

\section{ACKNOWLEDGEMENTS}

We thank Tania Riveros, Luis Motta and Lino Olivares for their invaluable field assistance. We gratefully acknowledge the owners and administrators of the farms visited for their hospitality and assistance. The University of Atlántico and the Colombian National Herbarium allowed the use of their facilities for processing and identifying plant vouchers. Financial support was provided by Bournemouth University and Santander by means of a Travel Grant. C. Castellanos-Castro acknowledges to the Administrative Department of Science, Technology and Innovation of Colombia (COLCIENCIAS) for a PhD scholarship grant.

\section{BIBLIOGRAFIC REFERENCES}

Ackerly, D. (2004). Functional strategies of Chaparral shrubs in relation to seasonal water deficit and disturbance. Ecological Monographs, 74, 25-44.

Baraloto C., Paine, C.E.T., Poorter, L., Beauchene, J., Bonal, D., Domenach, A-M., Hérault, B., Patiño, S., Roggy, J-C., \& Chave, J. (2010). Decoupled leaf and stem economics in rain forest trees. Ecology Letters, 13, 1338-1347.

Brando, P.M., Nepstad, D.C, Balch, J.K, Bolker, B., Christman, M.C., Coe, M., \& Putz, F.E. (2012). Fireinduced tree mortality in a neotropical forest: the role of bark traits, tree size, wood density and fire behaviour. Global Change Biology, 18, 630-341.

Chave, J. (2005). Measuring wood density for tropical forest trees. A field manual for the CTFS sites. $7 \mathrm{p}$.

Chave, J., Coomes, D., Jansen, S., Lewis, S.L., Swenson, N.G., \& Zanne, A.M. (2009). Towards a worldwide wood economics spectrum. Ecology Letters, 12, 351-366.

Chatuverdi, R.K., Raghubanshi, A.S., \& Singh, J.S. (2011). Plant functional traits with particular reference to tropical deciduous forests: a review. Journal of Biosciences, 36(5), 1-19. 
Chazdon, R.L., Finegan, B., Capers, R.S., SalgadoNegret, B., Casanoves, F., Boukili, V., \& Norden, N. (2010). Composition and dynamics of functional groups of trees during tropical forest succession in northeastern Costa Rica. Biotropica, 42, 31-40.

Choat, B., Ball, M.C., Luly, J.G., \& Holtum, J.A.M. (2005). Hydraulic architecture of deciduous and evergreen dry rainforest tree species from northeastern Australia. Trees, 19, 305-311.

Cornelissen, J.H.C., Lavorel, S., Garnier, E., Díaz, S., Buchmann, N., Gurvich, D.E., Reich P.B., ter Steege, H., Morgan H.D., van der Heijden, M.G.A., Pausas, J.G., \& Poorter, H. (2003). A handbook of protocols for standardised and easy measurement of plant functional traits worldwide. Australian Journal of Botany, 51, 335-380.

Díaz, S., \& Cabido, M. (1997). Plant functional types and ecosystem function in relation to global change. Journal of Vegetation Science, 8, 463-474.

Díaz, S., \& Cabido, M. (2001). Vive la difference: plant functional diversity matters to ecosystem function. Trends in Ecology and Evolution, 16, 646-655.

Díaz, S., Hodgson, J.G., Thompson, K., Cabido, M., Cornelissen, J.H.C., Jalili, A., MontserratMartí, G., Grime, J.P., Zarrinkamar, F., Asri, Y, Band, S.R., Basconcelo, S., Castro-Díez, P., Funes, G., Hamzehee, B., Khoshnevi, M., PérezHarguindeguy, N., Pérez-Rontomé, M.C., Shirvany, F.A., Vendramini, F., Yazdani, S., Abbas-Azimi, R., Bogaard, A., Boustani, S., Charles, M., Dehghan, M., de Torres-Espuny, L., Falczuk V., GuerreroCampo, J., Hynd, A., Jones, G., Kowsary, E., Kazemi-Saeed, F., Maestro-Martínez, M., RomoDíez, A., Shaw, S., Siavash, B., Villar-Salvador, P., \& Zak, M.R. (2004). The plant traits that drive ecosystems: evidence from three continents. Journal of Vegetation Science, 15, 295-304.

Easdale, T., Gurvich, D.E., Sersic, A.N., \& Healey, J.R. (2007). Tree morphology in seasonally dry montane forest in Argentina: relationships with shade tolerance and nutrient storage. Journal of Vegetation Science, 18, 313-326.

Enquist, B.J., \& Enquist, C.A.F. (2011). Long-term change within a Neotropical forest: assessing differential functional and floristic responses to disturbance and drought. Global Change Biology, 17, 1408-1424.

Finn, J.A., Kirwan, L., Connolly, J., Sebastià M.T., Helgadottir, A., Baadshaug, O.H, Bélanger, G., Black, A., Brophy, C., Collins, R.P., Čop, J., Dalmannsdóttir, S., Delgado, I., Elgersma, A., Fothergill, M., Frankow-Lindberg, B.E., Ghesquiere, A., Golinska, B., Golinski, P., Grieu, P., Gustavsson, A-M., Höglind, M., Huguenin-Elie, O., Jørgensen, M., Kadziuliene, Z., Kurki, P., Llurba, R., Lunnan, T., Porqueddu, C., Suter, M., Thumm, U., \& Lüscher, A. (2013). Ecosystem function enhanced by combining four functional types of plant species in intensively managed grassland mixtures: a 3-year continental-scale field experiment. Journal of Applied Ecology, 50, 365-375.

Fortunel, C., Fine, P.V.A., \& Baraloto, C. (2012). Leaf, stem and root tissue strategies across 758 Neotropical tree species. Functional Ecology, 26, 1153-1161.

Fry, E., Manning, P., Allen, D.G.P., Hurst, A., Everwand, G., Rimmler, M., \& Power, S.A. (2013). Plant functional group composition modifies the effects of precipitation change on grassland ecosystem function. PLoS ONE, 8(2), e57027.

García, H., Corzo, G., Isaacs, P., \& Etter, A. (2014). Distribución y estado actual de los remanentes del bioma bosque seco tropical en Colombia: insumos para su gestión. En C. Pizano \& García, H. (eds.). El bosque seco tropical en Colombia (pp.229-251). Bogotá D.C.: Instituto de Investigación de Recursos Biológicos Alexander von Humboldt (IAvH).

Gentry, A.H. (1995). Diversity and floristic composition of neotropical dry forest. En S.H. Bullock, Mooney, H.A. \& Medina, E. (eds.). Seasonally dry tropical forests (pp.146-194). Cambridge: Cambridge University Press.

Gilbert B., Wright, S.J., Muller-Landau, H.C., Kitajima, K., \& Hernandéz, A. (2006). Life history tradeoffs in tropical trees and lianas. Ecology, 87(5), 1281-1288.

Grime, J.P. (1977). Evidence for the existence of three primary strategies in plants and its relevance to 
ecological and evolutionary theory. The American Naturalist, 111, 1169-1194.

Grime, J.P., Thompson, K., Hunt, R., Hodgson, J.G., Cornelissen, J.H., Rorison, I.H., Hendry, G.A.F., Ashendenl, T.W., Askew, A.P., Band, S.R., Booth, R.E., Bossard, C.C., Campbell, B.D., Cooper, J.E.L., Davison, A.W., Gupta, P.L., Hall, W., Hand, D.W., Hannah, M.A., Hillier, S.H., Hodkinson, D.J., Jalili, A., Liu, Z., Mackey, J.M.L., Matthews, N., Mowforth, M. A., Neal, A.M., Reader, R.J., Reiling, K., Ross-Fraser, W., Spencer, R.E., Sutton, F., Tasker, D.E., Thorpe, P.C., \& Whitehouse, J. (1997). Integrated screening validates primary axes of specialization in plants. Oikos, 79, 259-281.

Hennig, C. (2014). fpc: Flexible procedures for clustering. R package version 2.1-7. Available at http://CRAN.R-project.org/package $=$ fpc

Hillebrand, H., \& Mathiesssen, B. (2009). Biodiversity in a complex world: consolidation and progress in functional diversity research. Ecology Letters, 12, 1405-1419.

Khurana, E., Sagar, R., \& Singh, J.S. (2006). Seed size: a key trait determining species distribution and diversity of dry tropical forest in northern India. Acta Oecologica, 29, 196-204.

Kitajima, K., \& Poorter, L. (2010). Tissue-level leaf toughness, but not lamina thickness, predicts sapling leaf lifespan and shade tolerance of tropical tree species. New Phytologist, 186, 708-721.

Kraft, N.J.B., Metz, M.R., Condit, R.S., \& Chave, J. (2010). The relationship between wood density and mortality in a global tropical forest data set. New Phytologist, 188, 1124-1136.

Laliberté, E., Wells, J.A., DeClerck, F., Metcalfe, D.J., Catterall, C.P., Queiroz, C., Aubin, I., Bonser, S.P., Ding, Y., Fraterrigo, J.M., McNamara, S., Morgan, J.W., Sánchez Merlos D., Vesk, P.A., \& Mayfield, M.M. (2010). Land-use intensification reduces functional redundancy and response diversity in plant communities. Ecology Letters, 13, 76-86.

Lavorel, S., Díaz, S., Cornelissen, J.H.C., Garnier, E., Harrison, S.P., McIntyre, S., Pausas, J.G., PérezHarguindeguy, N., Roumet, C., \& Urcelay, C.
(2007). Plant Functional Types: Are We Getting Any Closer to the Holy Grail? In J.G. Canadell, Pataki, D.E. \& Pitelka, L.F. (eds.). Terrestrial ecosystems in a changing world (pp. 149-164). The IGBP Series. Berlin and Heidelberg: Springer-Verlag,

Lebrija-Trejos, E., Pérez-García, E.A., Meave, J.A., Poorter, L., \& Bongers, F. (2009). Environmental changes during secondary succession in a tropical dry forest in Mexico. Journal of Tropical Ecology, 27, 477-489.

Maechler, M., Rousseeuw, P., Struyf, A., Hubert, M., \& Hornik, K. (2012). Cluster: Cluster Analysis Basics and Extensions. R package version 1.14.3. Available at http://cran.rproject.org/web/packages/ cluster/index.html

Malhado, A.C.M., Malhi, Y., Whittaker, R.J., Ladle, R.J., ter Steege, H., Phillips, O.L., Butt, N., Aragão, L.E.O.C., Quesada, C.A., Araujo-Murakami, A., Arroyo, L., Peacock, J., Lopez-Gonzalez, G., Baker, T.R., Anderson, L.O., Almeida, S., Higuchi, N., Killeen, T.J., Monteagudo, A., Neill, D., Pitman, N., Prieto, A., Salomão, R.P., Vásquez-Martínez, R., \& Laurance, W.F. (2009). Spatial trends in leaf size of Amazonian rainforest trees. Biogeosciences, 6, 1563-1576.

Malhado, A.C.M., Whittaker, R.J., Malhi, Y., Ladle, R.J., ter Steege, H., Phillips, O., Aragão, L.E.O.C., Baker, T.R., Arroyo, L., Almeida, S., Higuchi, N., Killeen, T.J., Monteagudo, A., Pitman, N.C.A., Prieto, A., Salomão, R.P., Vásquez-Martínez, R., Laurance, W.F., \& Ramírez-Angulo, H. (2010). Are compound leaves an adaptation to seasonal drought or to rapid growth? Evidence from the Amazon rain forest. Global Ecology and Biogeography, 19, 852-862.

Markesteijn, L., \& Poorter, L. (2009). Seedling root morphology and biomass allocation of 62 tropical tree species in relation to drought- and shadetolerance. Journal of Ecology, 97, 311-325.

Markesteijn, L. Poorter, L., Paz, H., Sack, L., \& Bongers, F. (2010). Ecological differentiation in xylem cavitation resistance is associated with stem and leaf structural traits. Plant, Cell and Environment, 34, 137-148. 
Markesteijn, L., Poorter, L., Bongers, F., Paz, H., \& Sack, L. (2011). Hydraulics and life history of tropical dry forest tree species: coordination of species' drought and shade tolerance. New Phytologist, 191, 480-495.

Mooney H.A., Bullock, S.H., \& Medina, E. (1995). Introduction. En S.H. Bullock, Mooney H.A. \& Medina E. (eds.). Seasonally dry tropical forests (pp. 1-8). Cambridge: Cambridge University Press.

Niinemets, Ü., Portsmuth, A., \& Tobias, M. (2006). Leaf size modifies support biomass distribution among stems, petioles and mid-ribs in temperate plants. New Phytologist, 171, 91-104.

Oksanen, J., Blanchet, F.G., Kindt, R., Legendre, P., Minchin, P.R., O'hara, R.B., Simpson, G.L., Solymos, P., Stevens, M.H.H., \& Wagner, H. (2012). Vegan: Community Ecology Package. R package version 2.0-5. Available at http://CRAN.R-project. org/package=vegan

Onoda, Y., Westoby, M., Adler, P.B., Choong, A.M.F., Clissold, F.J., Cornelissen, J.H.C., Díaz, S., Dominy, N.J., Elgart, A., Enrico, L., Fine, P.V.A., Howard, J.J., Jalili, A., Kitajima, K., Kurokawa, H., McArthur, C., Lucas, P.W., Markesteijn, L., Pérez-Harguindeguy, N., Poorter, L., Richards, L., Santiago L.S., Sosinski, E.E. Jr., Van Bael, S.A., Warton, D.I., Wright, I.J., Wright, S.J., \& Yamashita, N. (2011). Global patterns of leaf mechanical properties. Ecology Letters, 14(3), 301-312.

Paine, C.E.T., Stahl, C., Courtois, E.A., Patiño, S., Sarmiento, C., \& Baraloto, C. (2010). Functional explanations for variation in bark thickness in tropical rain forest trees. Functional Ecology, 24, 1202-1210.

Patiño, S., Fyllas, N.M., Baker, T.R., Paiva, R., Quesada, C.A., Santos, A.J.B., Schwarz, M., ter Steege, H., Phillips, O.L., \& Lloyd, J. (2012). Coordination of physiological and structural traits in Amazon forest trees. Biogeosciences, 9, 775-801.

Pineda-Garcia, F., Paz, H., \& Tinoco-Ojanguren, C. (2011). Morphological and physiological differentiation of seedlings between dry and wet habitats in a tropical dry forest. Plant, Cell and Environment, 34, 1536-1547.
Pineda-Garcia, F., Paz, H., \& Meinzer, F.C. (2013). Drought resistance in early and late secondary successional species from a tropical dry forest: the interplay between xylem resistance to embolism, sapwood water storage and leaf shedding. Plant, Cell and Environment, 36, 405-418.

Pizano, C., González-M., R., González M.F., Castro-Lima, F., López, R., Rodríguez, N., Idárraga-Piedrahíta, A., Vargas, W., Vergara-Varela, H., Castaño-Naranjo, A., Devia, W., Rojas, A., Cuadros, H., \& Toro, J.L. (2014) En C. Pizano \& García, H. (eds.). El bosque seco tropical en Colombia (pp. 49-93). Bogotá D.C.: Instituto de Investigación de Recursos Biológicos Alexander von Humboldt (IAvH).

Poorter, L. (2005). Resource capture and use by tropical forest tree seedlings and their consequences for competition. In D.F.R.P. Burslem, Pinard, M.A. \& Hartley, S.E. (eds.). Biotic Interactions in the Tropics (pp. 35-64). Cambridge: Cambridge University Press.

Poorter, L. (2007). Are species adapted to their regeneration niche, adult niche, or both? American Naturalist, 169(4), 433-442.

Poorter, L. (2009). Leaf traits show different relationships with shade in moist versus dry tropical forests. New phytologist, 191, 890-900.

Poorter, L., \& Bongers, F. (2006). Leaf traits are good predictors of plant performance across 53 rain forest species. Ecology, 87, 1733-1743

Poorter, L., \& Kitajima, K. (2007). Carbohydrate storage and light requirements of tropical moist and dry forest species. Ecology, 88, 1000-1011.

Poorter, L., and Markesteinj, L. (2008). Seedling traits determine drought tolerance in seedlings of tropical tree species. Biotropica, 40, 321-331.

Poorter, L., McDonald, I., Alarcón, A., Fichtler, E., Licona, J-C., Peña-Claros, M.,Sterck, F., Villegas, Z., \& Sass-Klaassen, U. (2010). The importance of wood traits and hydraulic conductance for the performance and life history strategies of 42 rainforest tree species. New Phytologist, 185, 481-492.

Powers, J., \& Tiffin, P. (2010). Plant functional type classifications in tropical dry forests in Costa Rica: 
leaf habit versus taxonomic approaches. Functional Ecology, 24, 927-936.

Pringle E. G., Adams R.I., Broadbent E., Busby P.E., Donatti C.I., Kurten E.L., Renton K., \& Dirzo R. (2010). Distinct leaf-traits syndromes of evergreen and deciduous trees in a seasonally dry tropical forest. Biotropica, 43, 299-308.

Rasband, W.S. \& Image J, U. S. (2011). National Institutes of Health, Bethesda, Maryland. Available at http://imagej.nih.gov/ij/, 1997-2011

Rodríguez, G. M., Banda-R, K., Reyes, S.P., \& Estupiñán, A.C. (2012). Lista comentada de las plantas vasculares de bosques secos prioritarios para la conservación en los departamentos de Atlántico y Bolívar (Caribe colombiano). Biota Colombiana, 13, 7-39.

Rüger, N., Huth, A., Hubbell, S.P., \& Condit, R. (2012). Response of recruitment to light availability across a tropical lowland rain forest community. Journal of Ecology, 97, 1360-1368.

Santiago, L.S., \& Wright, S.J. (2007). Leaf functional traits of tropical forest plants in relation to growth form. Functional Ecology, 21, 19-27.

Sanson, G., Read, J., Aranwela, N., Clissold, F., \& Peeters, P. (2001). Measurement of leaf mechanical properties in studies of herbivory: opportunities, problems and procedures. Austral Ecology, 26, 535-546.

Silvertown, J. (2004). Plant coexistence and the niche. Trends in Ecology and Evolution, 19, 605-611.

Sterck, F., Markesteijn, L., Schieving, F., \& Poorter, L., (2011). Functional traits determine trade-offs and niches in a tropical forest community. Proceedings of the National Academy of Sciences, 108, 20627-20632.

Schnitzer, S.A., \& Bongers, F. (2002). The ecology of lianas and their role in forests. Trends in Ecology and Evolution, 17(5), 223-230.

Tropicos (2013). Missouri Botanical Garden. Available at http://www.tropicos.org

Van der Sande, M., Poorter, L., Schnitzer, S.A., \& Markesteijn, L. (2013). Are lianas more droughttolerant than trees? A test for the role of hydraulic architecture and other stem and leaf traits. Oecologia, 172, 961-972.
Ward, S.E., Bardgett, R.D., McNamara, N.P., \& Ostle, N.J. (2009). Plant functional group identity influences short-term peatland ecosystem carbon flux: evidence from a plant removal experiment. Functional Ecology, 23, 454-462.

Wardle, D.A., Bonner, K.I., \& Barker, G.M. (2000). Stability of ecosystem properties in response to above-ground functional group richness and composition. Oikos, 89, 11-23.

Warman, L., Moles, A.T., \& Edwards, W. (2010). Not so simple after all: searching for ecological advantages of compound leaves. Oikos, 120(6), 813-821.

Weiher, E., van der Werf, A., Thompson, K., Roderick, M., Garnier, E., \& Eriksson, O. (1999). Challenging Theophrastus: a common core list of plant traits for functional ecology. Journal of Vegetation Science, 10, 609-620.

Westoby, M. (1998). A leaf-height-seed (LHS) plant ecology scheme. Plant and Soil, 199, 213-227.

Westoby, M., Falster, D.S., Moles, A.T., Vesk, P.A., \& Wright, I.J. (2002). Plant ecological strategies: some leading dimensions of variation between species. Annual Review of Ecology and Systematics, 33, 125-159.

Westoby, M., \& Wright, I.J. (2006). Land-plant ecology on the basis of functional traits. Trends in Ecology and Evolution, 21, 261-268.

Wilson, P.J., Thompson, K., \& Hodgson, J.G. (1999). Specific leaf area and leaf dry matter content as alternative predictors of plant strategies. New Phytologist, 143, 155-162.

Wright, I.J., \& Cannon, K. (2001). Relationships between leaf lifespan and structural defences in a low-nutrient, sclerophyll flora. Functional Ecology, 15(3), 351-359.

Wright, I.J., \& Westoby, M. (2002). Leaves at low versus high rain fall: coordination of structure, lifespan and physiology. New Phytologist, 155, 403-416.

Wright, I.J., Reich, P.B., Westoby, M., Ackerly, D.D., Baruch, Z., Bongers, F., Cavender-Bares, J., Chapin, T., Cornelissen, J.H.C., Diemer, M., Flexas, J., Garnier, E., Groom, P-K., Gulias, J., Hikosaka, K, Lamont, B.B., Lee, T., Lee, W., Lusk, C., Midgley, J.J., Navas, M-L., Niinemets, U., Oleksyn, J., 
Osada, N., Poorter, H., Poot, P., Prior, L., Pyankov, V.I., Roumet, C., Thomas, S.C., Tjoelker, M.K., Veneklaas, E.J., \& Villar, R. (2004). The worldwide leaf economics spectrum. Nature, 428, 821-827.

Wright, I.J., Ackerly, D.A., Bongers, F., Harms, K.E., Ibarra-Manriquez, G., Martínez-Ramos, M., Mazer, S.J., Muller-Landau, H.C., Paz, H., Pitman, N.C.A., Poorter, L., Silman, M.R., Vriesendorp, C.F., Webb, C.O., Westoby, M., \& Wright, S.J. (2007). Relationships among ecologically important dimensions of plant trait variation in seven neotropical forests. Annals of Botany, 99, 1003-1015.

Wright, S.J., Kitajima, K., Kraft, N.J.B., Reich, P.B., Wright, I.J., Bunker, D.E., Condit, R., Dalling, J. W., Davies, S.J., Díaz, S., Engelbrecht, B.M.J., Harms, K.E., Hubbell, S.P., Marks, C.O., Ruiz-Jaen, M.C., Salvador, C.M., \& Zanne, A.E. (2010). Functional traits and the growth-mortality trade-off in tropical trees. Ecology, 91, 3664-3674. 